\section{Transgender women and the Gender Reassignment Process: subjection experiences, suffering and pleasure in body adaptation}

\author{
Mulheres transexuais e o Processo Transexualizador: \\ experiências de sujeição, padecimento e prazer na adequação do corpo \\ Mujeres transgénero y el Proceso Transexualizador: \\ experiências de sometimiento, sufrimiento y placer en la adecuación del cuerpo
}

\section{Analídia Rodolpho Petry}

\section{ABSTRACT}

Objective: This article seeks to understand the experiences of transgender women in relation to the hormone therapy and sex reassignment surgery that make up the Gender Reassignment Process.

Method: It is a qualitative study inserted into the field of cultural and gender studies. Data collection used narrative interviews, conducted in 2010 and 2011, with seven transsexual women who had been undergoing the Gender Reassignment Process for at least two years. The data was submitted to a thematic analysis.

Results: The results show that the transformation processes for construction of the female body include behavior adaptation, posture modification, voice modulation, hormone use, vaginal canal dilation and surgical complications. Such processes subject the body to be built as idealized to fit the gender identity, infringing on pleasures and afflictions.

Conclusion: We concluded that the discussion involving the Gender Reassignment Process brings allowances for nursing regarding body changes experienced by transgender women.

Keywords: Sex reassignement surgery. Transgendered persons. Gender identity.

\section{RESUMO}

Objetivo: Neste artigo, busca-se compreender as experiências de mulheres transexuais em relação à hormonioterapia e à cirurgia de redesignação sexual que constituem o Processo Transexualizador.

Método: Trata-se de uma pesquisa qualitativa inserida no campo dos estudos culturais e de gênero. A coleta de dados utilizou entrevistas narrativas, realizadas em 2010 e 2011 com sete mulheres transexuais que se submeteram ao Processo Transexualizador há, pelo menos, dois anos. Os dados foram submetidos à análise temática.

Resultados: Os resultados mostram que os processos de transformação para a construção do corpo feminino envolvem adequar o comportamento, postura, empostação da voz, uso de hormônios, dilatação do canal vaginal e complicações cirúrgicas. Tais processos sujeitam o corpo a se construir conforme idealizado para adequar-se a sua identidade de gênero, infringindo-lhe prazeres e padecimentos.

Conclusão: Conclui-se que a discussão que envolve o Processo Transexualizador traz subsídios para a enfermagem acerca das modificações corporais vivenciadas pelas mulheres transexuais.

Palavras-chave: Cirurgia de readequação sexual. Pessoas transgênero. Identidade de gênero.

\section{RESUMEN}

Objetivo: Esta investigación busca entender experiencias de mujeres transexuales con relación a la terapia hormonal y cirugía de reasignación de sexo, que constituyen el Proceso Transexualizador.

Método: Se trata de una investigación cualitativa ubicada en el campo de los Estudios Culturales y de Género. Para la recolección de datos se utilizó la entrevista narrativa, llevada a cabo entre enero de 2010 y diciembre de 2011 con siete mujeres transexuales que se sometieron a la totalidad del Proceso Transexualizador por, un mínimo de dos años. Los datos fueron sometidos a análisis temático. Resultados: Los resultados muestran que la construcción de un cuerpo femenino implica procedimientos para cambiar el comportamiento, postura, el tono de voz, el uso de la terapia hormonal, dilatación del canal vaginal y complicaciones quirúrgicas. Estos procesos someten al cuerpo a construirse como fue diseñado para adaptarse a su identidad de género, causando placeres y sufrimientos. Conclusión: Este estudio muestra que la discusión del Proceso Transexualizador trae subsidios para enfermería acerca de los cambios corporales que experimentan las mujeres transexuales.

Palabras clave: Cirugía de reasignación de sexo. Personas trasgénero. Identidad de género.
D0l: $\quad$ http://dx.doi.org/10.1590/1983-

1447.2015.02.50158 a Nurse, PhD in Nursing, member of the UNISC Group
for Health Study and Research, professor at the Uni-
versidade de Santa Cruz do Sul, RS, Brazil. 


\section{DINTRODUCTION}

This article is part of a doctoral thesis ${ }^{(1)}$ and its purpose is to understand the experiences of transgender women in relation to hormone therapy and sex reassignment surgery for transsexuals, which make up the Gender Reassignment process. The main purpose is to investigate how the transformation processes for construction of the female body were experienced by transgender women. The discussions carried out are based on the assumption that this issue should be widely explored in the field of nursing since it plays a direct role in all stages of the Gender Reassignment Process. Nevertheless, this discussion has been minimally explored in undergraduate nursing courses ${ }^{(2-3)}$.

Such discussions are important, since an increasing number of people are seeking to change their body to the gender with which they identify. Gender, in this study, is understood as the behavior of each individual vis-à-vis society, according to their cultural interpretation of the sex, while sex refers to the biological male or female binary pattern. Such discussions are based on a performative theory of gender ${ }^{(4-5)}$.

For better understanding of the issue addressed, it is necessary to understand what is diagnosed, in the biomedical discourse, as transsexual. To be considered transsexual, the individual must present anatomical characteristics of a given biological sex, without physical differences compared to his or her peers. Although there are no apparent differences from an anatomical, chromosomal, hormonal and somatic standpoint, there must be a personal awareness of belonging to the other sex ${ }^{(2)}$. Individuals with intersex conditions such as androgen insensitivity syndrome, congenital adrenal hyperplasia and ambiguous genitalia are not considered transsexual(6).

The aspect that demands trans-sexuality be identified as a category that differs from the others is the desire and internal, constant and permanent need for the sexual change presented. The life story of the individual is considered fundamentally important to the development of what is considered to be a diagnosis of trans-sexuality ${ }^{(6)}$.

In the biomedical discourse, for each clinical condition there is a recommended treatment. In trans-sexuality, the treatment provided by the Unified Health System is known as Gender Reassignment Process ${ }^{(7)}$. The protocols that standardize follow the recommendations set by the World Psychiatry Association for Transgender Health (WPATH) ${ }^{(8)}$. The procedure recommended by this institution is composed of two phases, divided into several stages. The first relates to confirmation of the diagnosis. The second, which includes three steps, is called Triadic Therapy.

The first phase of the Gender Reassignment Process begins when the individual seeks out the specialized service, where he or she will visit with different professionals who will interview the patient. The individual will undergo psychometric tests and have clinical examinations. He or she will also have consultations with a multidisciplinary team consisting of a doctor, psychologist, nurse, social worker and speech therapist ${ }^{(7-8)}$. Procedures that make up this phase take time and function so that professionals know both the past personal history as well as the motivations that lead individuals to seek sex reassignment surgery (SRS), to assess whether the person meets the diagnostic criteria for Gender Dysphoria(6).

Once considered transsexual, the second phase of the Gender Reassignment Process begins, which includes three steps. They occur simultaneously or sequentially, and last for two years. These steps consist of evaluating the experience of the individual in the role of the desired gender, in hormonal therapy and in surgery, both to change physical characteristics (such as breasts and face) as well as gender reassignment surgery ${ }^{(7-9)}$. One of these steps refers to an assessment of the experience of the individual in the gender identification role. It is known as real life experience and permeates the entire period that the individual is being accompanied by the health team. During this period the individual will be helped to behave according to the socially accepted model of femininity. Individuals will be guided on how to carry their bodies, for example, ways of sitting, walking and voice modulation ${ }^{(10)}$. Initiate the administration of hormones to alter secondary sexual characteristics, and, finally, SRS takes place, the last step in the Gender Reassignment Process.

It is understood that this research is justified, as it deals with issues that are current and that have undergone advances as a result of the struggles brought about by social movements linked to defending the rights of the LGBT population, and which led to the creation of Ordinance2836/ GM/MS, on December 2011, which established, under SUS, the National Comprehensive Health Policy for Lesbian, Gay, Bisexual, and Transgender Persons ${ }^{(11)}$. Furthermore, the Federal Medical Council replaced resolution 1652/02 with 1995/2010, thus allowing surgery using the Sigmoid CoIon Neo Vagina technique to be performed in any hospital, provided it complies with multidisciplinary monitoring for a period of two years ${ }^{(9)}$. Another breakthrough concerns Ordinance 2803, of November 19, 2013, which redefines and expands the Gender Reassignment Process for SUS(7).

\section{METHODOLOGY}

This research falls under the field of cultural and gender studies. It is a qualitative study that used the narrative interview, which dispenses a pre-structured script ${ }^{(12)}$. Inter- 
views were conducted with seven transgender women, in their homes, between January 2010 and December 2011 and there was no predetermined duration. The interviewees resided in the state of Rio Grande do Sul and met the following inclusion criteria: they had gone through the two-year Gender Reassignment Process and had had sex reassignment surgery at least two years prior. These criteria were established so that the research subjects were, at the time of interview, outside the hospital environment. The exclusion criterion was that the subject was still linked to hospital monitoring. The informants were identified from professional familiarity with the researcher. The number of respondents was established by transgender women who were identified in the data collection period and agreed to sign the Informed Consent, in accordance with Resolution 196/96. The study was approved according to protocol 2008119/2009, by the Federal University of Rio Grande do Sul Ethics Committee. To maintain the anonymity of the participants, we opted for the use of aliases, chosen by the participants themselves.

After the interviews, the speeches were transcribed in their entirety for further analysis of their content, in the thematic modality. The pre-analysis, material exploration and treatment of results steps were carried out. The data was organized according to the presence of certain elements that were repeated, ${ }^{(13)}$ according to the units that had the most significant meanings. The thematic units that emerged from the data included: "Hormone therapy and the production of a female body" and "sexual reassignment surgery and the construction of a female body." Data analysis was performed on the thematic modality and subsidized by the post-critical gender theories ${ }^{(4-5)}$.

\section{RESULTS AND DISCUSSION}

\section{Hormone therapy and the production of a female body}

The first thematic category deals with the experiences of transgender women in relation to hormone therapy, including issues related to the transformation processes that the interviewees went through ${ }^{(1)}$.

The heterogeneity of respondents, in terms of education, ranged from incomplete elementary school to masters degree holders; the age range was between twenty-eight and fifty-nine years old. Social class did not hinder the use of the narrative interview. And it is understood that narrating and telling one's own life story does not depend on the individuals' degree of academic education or language skills ${ }^{(12)}$.
During the two years of monitoring, transsexual women underwent hormone treatment for modification of secondary sexual characteristics. Physical changes produced by the use of hormones are considerable and easily perceived. One can achieve a significant increase in breast size, which become defined. It was evident that most of the interviewees had been living as the gender with which they identified in their daily lives ${ }^{(10,14)}$ and were taking hormones as indicated by people they knew:

One day, talking to a friend of mine, I said: I am so jealous, you have such large breasts and I have nothing! Then she said: take Microdiol! So I went to the pharmacy and then started taking Microdiol. But I was so mad because I wanted boobs quickly, I wanted to see my body change soon. So I bought three blister packs right away and took two or three pills a day! If I forgot, the next day I was already taking four, five, whatever! I wanted my body to be a female's body, you know? Then, after three months I began to see my breast grow! And they grew and grew! In nine months they became very large. I was a man with breasts, [laughs]! I had the face of a man and breasts! (Silvia)

The excerpt shows Sylvia's urgency to quickly produce a body with female characteristics. The inherent risks to the process of self-medication did not matter. She was interested in showing, through her body, the socially recognized sign of femininity that breasts represent.

The voice, which becomes more high pitched, is another characteristic that is changed by hormone therapy. Individuals who undergo the Gender Reassignment Process through public health services rely on speech therapy, which provides voice modulation training and exercises. The voice is characterized as an important element in identifying and assigning gender:

[...] I started taking hormones when I was twenty six years old [...] my voice is deep and it makes me very upset. My voice is a problem for me. So much so that on the phone people call me sir. And I respond: Not sir! It's ma'am! (Brígida)

The excerpt shows how much gender is performative, although presented as a natural dimension and essence of the female subject in the context of culture ${ }^{(4)}$. A female voice must be shrill. Health services take ownership of and standardize the gender learning processes that take effect in a naturalized way in the socialization processes to which we are subjected within the family, at school and in other social relationships and which turn us into women and men of certain types ${ }^{(5)}$. 
Estrogen affects the growth of hair, which may make it softer, decreasing its growth in some areas of the body. We observed that people have immense discomfort with the presence of the body hair on the face. Treatments, such as permanent hair removal or others, are expensive and painful. Removing the hair daily, by shaving, causes hair to grow more quickly and thicken. Various styles of makeup and waxing techniques are the subject of discussion and information exchange $\mathrm{e}^{(1,1,14-15)}$ among transgender women trying to fit the hegemonic model of femininity.

The effects of hormone therapy on the growth of hair also vary. In some people hair on the scalp grows quickly, becoming softer. In other cases, these changes are less noticeable. Another body characteristic affected by hormones concerns the distribution of body fat, which is modified by the administration of estrogen, softening the shape of the body, as Paula longed for:

[...] I started taking the pills [hormones] and in three months I had breasts! My body had changed! It became rounder, the hair lessened, I no longer have to shave as much [...]. (Paula)

Another aspect brought up by the interviewees refers to the interference of hormone therapy in relation to sexuality ${ }^{(16)}$. They show a marked reduction of erections, because there is atrophy of the prostate gland and seminal vesicles, as Joana and Paula state:

When I had relations [short pause] I think it was because of hormones, [points to the pubic area to indicate the penis] it did not raise, you know? It was so [other sign to indicate that the penis on these occasions remained curved]. (Joana)

[...] of course when I got excited, the thing was, why ... it is part of the body, right? But because of the hormones, I think, I did not have much [signals indicating erection]. (Débora)

Perceiving and naming the penis is almost prohibitive for Joana and Debora. To avoid speaking the word penis they confirm the diagnosis that determines that, to be a real woman, one must have an aversion to the male sex organ and not use it for the purpose of sexual gratification. Thus, through the diagnosis of trans-sexuality, ${ }_{1}^{(6-9)}$ they give meaning to the cluster of experiences that provide a way of signifying its existence ${ }^{(14)}$. For Débora, it displeased her to see the image of her body reflected in the mirror:

Well, then it started to bother me a lot. I always urinated sitting down, you know? When I showered, I did not feel good looking at myself naked in front of the mirror [short pause]. Look in the mirror, naked? Never! I was terrified to wash my genitals! It was so horrific! I never used it, except to urinate. (Débora)

The diagnostic criteria that identifies the true transsexual through aversion to the genitals are widely criticized because they emphasize the disciplining power of the diagnosis that recommends that individuals have to feel sexual desire the way it is prescribed that should or could fee $\left.\right|^{(10.14)}$. It means submitting the body not only to performing expressions of gender, but it goes beyond, aiming to create ways of feeling this body, subjecting it to realize sensations as socially prescribed, leaving no room for other possibilities of existence.

Mood is also affected by the use of estrogen. People report that they are more sensitive and cry for any reason whatsoever. These effects eventually end up defining, in the individual, the representation of a feature that our culture naturalizes as being feminine. She would now be more of a woman. It is a side effect that gives the body, flooded with female hormones, dimensions of what is recognized as being a female identity ${ }^{(17)}$. Silvia says that:

[...] with the hormones we become more weepy, more sensitive [pause]. Which is a very womanly thing, right? (Silvia)

The side effects of estrogen therapy are made up by an important aspect that transsexual women would need to know. These effects include deep vein thrombosis, changes thromboembolisms, increased blood pressure, liver abnormalities and bone problems ${ }^{(18)}$. Despite the risks of treatment, they decide to use it to reach their goals $s^{(1,10,14)}$. It is clear that experiencing sensations perceived as female allow the interviewee to fit the requirements to be recognized - and feel recognized - as a human.

\section{Sexual reassignment surgery and the construction of a female body}

The second thematic category emerged from the data and deals with the surgical procedure in which the Gender Reassignment Process culminates. However, there are other surgical procedures that are included in the process. It is understood that these processes constitute transformation passages, involving actions that aim to fit, conform and frame the transsexual person so that he or she takes on the framed positions subject to socially acceptable femininity or masculinity ${ }^{(1)}$. The concept of the transformation passage is developed with help from the Gender Migration 
Theory ${ }^{(19)}$. Transsexual individuals are always and tirelessly, buying tickets, (through the aesthetic, cosmetic and surgical procedures they undergo), to a place where they can feel belonging, feel included and feel accepted by others and by themselves. Among the procedures performed to transform and shape the body and signify it as feminine are rhinoplasty, cricothyroid approximation and silicone breast and buttock implants.

The surgery for constructing a vagina using the individual's penis is the most used technique and has been improved. The skin of the penis and the scrotum is inverted to produce the vaginal canal and labia minora and majora. Aesthetically it is what presents the best results ${ }^{(20)}$. Surgical complications are considered easy to resolve, which, when it comes to surgery, does not mean they have a simple solution.

For this research, which studied only female transsexuals who had gone through the two-year process and transsexuals whose SRS had been done at least two years prior, some aspects related to surgery should be emphasized. The size of the vaginal canal, both in length and in width, depends on the amount of penile skin, which means that it may result in a neovagina that is not very long. After the surgery has been performed, the individual should remain on bed rest for four or five days. The vaginal dilator, placed during surgery may be removed on the fifth day and the individual can then walk around. The neovagina should be cleaned daily with an aqueous iodophor. The urinary catheter is removed on the day of hospital discharge.

Post-operative care involves handling the vaginal dilator and the hygiene of the vaginal canal. The removal of the vaginal dilator is gradual and occurs between the third and sixth month after surgery. Weekly dilatation routines may be required. For patients who maintain sexual relationships, vaginally, using the expander may no longer be necessary ${ }^{(20)}$. One of the possible consequences of SRS is loss of sensation in the genital region, as stated by Débora:

[...] I feel pleasure, yes. Of course it is not all that, because it went numb after surgery and everything. But I feel it, yes, I feel relaxed after and I enjoy having sex, you know? So there is also that. After the surgery, I never had anal sex anymore. I love to have sex in the front! (Débora)

Positioning your body to face the partner without the penis "to get in the way," as Débora also states, means that you feel like a woman, performing the feminine aspect that gives you more pleasure than the feeling of the orgasm itself. Postoperative complications are minimized given the prospect of being able to feel like a woman. Another possible complication is urethral stricture, which happened to Silvia:
[...] I had problems with the urethra. It closed. So I went to the hospital, and they put a catheter in, without anesthesia or anything. It hurt so badly. I went home and had to keep the catheter in for a week. (Silvia)

Other complications have been reported, among which we can point out: bleeding, infections or wounds. One complication related to vaginoplasty is a rectovaginal fistula, because the neovagina is built between the previous prostatic urethra and the posterior rectus ${ }^{(20)}$. The rectal wall is thin and care should be taken to avoid possible perforations. In such cases, the repair is surgery. Bridget's story brings postoperative complications to light, which included:

(...) I went to help get on the stretcher and everything came out. I started hemorrhaging! They called a doctor who came and helped, an assistant of the Dr. who operated on me. He pushed hard, put everything back inside. So stupid! He pushed it all back in and it stuck in the intestine. I almost died because of that! I spent a month in the hospital and went to the ICU and everything! (...) A year later, when I went to widen the vaginal canal, it was that little bit of vagina I had that got stuck to my intestine! (Brígida)

Despite postoperative problems, all interviewees emphasized that they would do it all again, to adapt their body to their gender identity in a constant search for transformational passages leading to the idealized female body.

Before we have surgery, we are freaks, yes indeed! What is a woman with a thing between her legs? Normal is when there isn't one! It's something that does not have a name! I heard it called and aberration one day and I thought: that is it! That's how I feel! A nameless thing, a freak of nature! (Joana)

We noticed that, with a diagnosis of trans-sexuality as a fixed and unchanging condition, the transsexual women interviewed give meaning to their human existence. Being recognized as a social being dependent on experiences of recognition ${ }^{(4)}$, for them, proved vital.

\section{口INAL CONSIDERATIONS}

The themes analyzed in this article suggest that a diagnosis of trans-sexuality is an identity marker. It involves a number of elements related to gender concepts that articulate a performing body - the model of a woman and femininity - establishing a fixed place for trans-sexuality as a pathology.

Interviews analyzed, from the guiding question, allowed us to understand the processes they go through 
and are described using various themes, including the construction of a socially acceptable woman's body, self disgust by image of the phallus, training of a softer voice as a sign of femininity, and the surgical process and its complications. These are some of the steps that transsexual women took - and take - towards gender identification. Such processes occur in a gradual way, throughout their life, through various undertakings of transformational passages. The Gender Reassignment Process does not end with SRS. It is necessary to consider that, according to these women, there is still much to do because it is daily construction of an identity.

Through the narratives we noted that transgender women occupy multiple positions on the subject, in constant search for social recognition of their human legitimacy. It means subjecting the body not only to performing expressions of gender, but goes beyond, aiming to create ways of feeling this body, subjecting it to perceiving sensations as socially prescribed, leaving no room for other possibilities of existence. We conclude that the discussion involving the Gender Reassignment Process presents aids for nursing related to body changes experienced by women, which need to be implemented in the care provided for this population. It is understood that one limitation of the study concerns the inclusion criteria, which made it difficult to find other transsexual women who had gone through SRS. New research on this issue needs to be carried out so that we can better understand the difficulties and the possibilities in the practice of care for this population.

\section{DEFERENCES}

1. Petry AR. Migraçōes sexuais e de gênero: experiências de mulheres transexuais [tese]. Porto Alegre (RS): Escola de Enfermagem, Universidade Federal do Rio Grande do Sul; 2011.

2. Matão MEL, Miranda DB, Campos PH, Teles MNA, Mesquita LB. Representaçōes sociais da transexualidade: perspectivas dos acadêmicos de enfermagem e medicina. Rev Baiana Saúde Pública. 2010;34(1):101-18.

3. Moreira MA, Gomes AJM. Representaçōes sociais de estudantes concluintes de enfermagem sobre transexualidade. Rev Enferm UFPE on line. 2013;7(5):4378-88.

4. Butler, J. Desdiagnosticando o gênero. Rios, A, tradutor. Physis [Internet]. 2009 [cited 2015 may 6];19(1):95-126. Available at: http://www.scielo.
br/scielo.php?script=sci_pdf\&pid=S010373312009000100006\&lng=pt $\& n r m=i s o \& t \operatorname{lng}=p t$

5. Meyer DEE. Corpo e gênero: teoria e política. In: Louro GL, Neckel JF, Goellner SV, organizadores. Corpo, gênero e sexualidade: um debate contemporâneo na educação. 9. ed. Petropólis: Vozes; 2013. p. 9-27.

6. Manual Diagnóstico e Estatístico de Transtornos Mentais: DSM-V. Porto Alegre: Artes Médicas; 2014.

7. Ministério da Saúde (BR). Portaria nº 2803 de 19 de novembro de 2013. Redefine e amplia o Processo Transexualizador no Sistema Único de Saúde (SUS) [Internet]. Brasília; 2013 [citado 2014 ago. 05]. Available at: http://bvsms.saude. gov.br/bvs/saudelegis/gm/2013/prt2803_19_11_2013.html

8. The Harry Benjamin International Gender Dysphorya Association's Standards of Care for Gender Identity Disorder, Sixth Version [Internet] 2001. [Cited 2010 mar. 25]. Available at: http://www.cpath.ca/wp-content/uploads/2009/12/ WPATHsocv6.pdf

9. Conselho Federal de Medicina (BR). Resolução No 1995/10. Dispõe sobre a cirurgia de transgenitalismo e revoga a resolução CFM nº 1652/02 [Internet] 2010. [cited 2014 aug. 05]. Available at: http://www.portalmedico.org.br/resolucoes/ CFM/2010/1955_2010.htm

10. Bento B. Na escola se aprende que a diferença faz a diferença. Rev Estud Fem. 2011;19(2): 549-59.

11. Ministério da Saúde (BR). Portaria № 2836, de $1^{\circ}$ dezembro de 2011. Institui, no âmbito do Sistema Único de Saúde (SUS), a Política Nacional de Saúde Integral de Lésbicas, Gays, Bissexuais, Travestis e Transexuais (Política nacional de saúde Integral LGBT). [Internet] 2011. [cited 2014 ago. 05]. Available at: http://bvsms. saude.gov.br/bvs/saudelegis/gm/2011/prt2836_01_12_2011.html

12. Larrosa J. Pedagogia profana: danças, piruetas e mascaradas. 5. ed. Belo Horizonte: Autêntica; 2010.

13. Bardin L. Análise de conteúdo. Lisboa: Edições 70; 2011.

14. Teixeira FB. Histórias que não têm era uma vez: as (in)certezas da transexualidade. Rev Estud Fem. 2012;20(2):501-12.

15. Oliveira MJ. Uma etnografia sobre 0 atendimento psicoterapêutico a transexuais. Rev Estud Fem. 2014;22(3):839-62.

16. Ettner R, Wyllie K. Psychological and social adjustment in older transsexual people. Maturitas. 2012;74(3):226-9.

17. Santos ART. A experiência da hormonioterapia das transexuais em Maceió/AL. Latitude. 2013;7(1):129-47.

18. Mueller A, Zollver H, Kronawitter D, Oppelt PG, Claassen T, Hoffmann I, et al. Body composition and bone mineral density in male-to-female transsexuals during cross-sex hormone therapy using gonadotrophin-releasing hormone agonist. Exp Clin Endocrinol Diabetes. 2011;119(2):95-100.

19. Ekins R, King D. Gender migration and citizenship. In: The Eighth International Gender Dysphoria Conference; 2004; Manchester, England. p 85-92.

20. Monstrey S, Selvaggi G, Ceulemans P. Surgery: male-to-female patient. In: Ettner $R$, Monstrey $S$, Eyler AE, organizadores. Principles of transgender medicine and surgery. New York: The Harworth Press; 2007. p.105-134.

\section{Author's address:}

Analídia Rodolpho Petry

Av. Independência, 2293, Universitário

96815-900 Santa Cruz do Sul - RS

E-mail:petry@unisc.br
Received: 10.09.2014

Approved: 01.06.2015 